\title{
Phenotypic and Genotypic Characteristics and Resistance Profile of Staphylococcus spp. from Bovine Mastitis
}

\author{
Érica Chaves Lúcio', Gisele Veneroni Gouveia², Mateus Matiuzzi da Costa², \\ Junior Mário Baltazar de Oliveira ${ }^{3}$, Rinaldo Aparecido Mota ${ }^{3} \&$ José Wilton Pinheiro Junior ${ }^{3}$
}

\begin{abstract}
Background: Bovine mastitis remains one of the health problems that cause the most damage to milk producers. The negative impact of mastitis is due to reduced milk production, early slaughter of females, reduced commercial value of the affected animals, losses in the genetic potential of the herd, expenses with medicines and veterinary medical assistance. Staphylococcus spp. stands out as the cause of this disease and has been able to remain in the mammary gland, becoming resistant to several antimicrobials. The aims of the present study were to characterize the phenotypes, genotypes and resistance profiles of Staphylococcus spp. isolates from bovine mastitis cases in the state of Pernambuco, Brazil.

Materials, Methods \& Results: These isolates were classified according to biochemical tests and the presence of the nuc gene. The polymerase chain reaction (PCR) for amplification of the mecA and blaZ genes was used to analyze the genetic potentials of antimicrobial resistance. Isolates were also phenotypically tested for resistance to nine antimicrobials (ampicillin, doxicillin, erythromycin, gentamicin, rifampicin, cephalothin, amoxicillin, nalidixic acid and oxacillin). The genetic potentials for biofilm production were evaluated by the amplifications of the icaD, icaA and bap genes. The phenotypic test of gentian violet was used for biofilm formation analyzes. Ninety-three (93.0\%) of the isolates among the Staphylococcus spp. samples were classified as Staphylococcus aureus. The lowest percentage of sensitivity observed was for amoxicillin (28.0\%). All of the isolates were sensitive to erythromycin and gentamicin, and $15(15 \%)$ exhibited sensitivity to all of the drugs tested. All of the isolates were negative for the mecA gene, and $36(36 \%)$ were positive for blaZ. In the adhesion microplate tests, 44 (44\%) of the isolates were capable of biofilm formation. Of these, seven (15.9\%) were strong formers, whereas $16(36.3 \%)$ and $21(47.8 \%)$ were moderate and weak formers, respectively. The icaD gene was confirmed in $89(89 \%)$ of the isolates. The icaA gene was confirmed in 61 (61\%) samples, and the bap gene in 52 (52\%) samples. One of the samples did not possess icaA, icaD or bap and exhibited moderate biofilm formation according to the microplate adherence test. Sixteen isolates simultaneously exhibited the three genes tested for biofilm production (icaA, icaD and bap) and were negative according to the microplate adherence test.

Discussion: The indiscriminate use of antibiotics to treat mastitis is a common practice in the study area, which may have contributed to the high proportion of herds $(88.23 \%$; 15/17) with multi-resistant isolates, constituting a selection factor for the dissemination of resistant bacteria among herds. The absence of the mecA gene in the present study may be associated with the development of resistant bacteria through another mechanism, such as the overproduction of beta-lactamases. The results demonstrate that antimicrobial resistance occurs in Staphylococcus spp. that cause bovine mastitis in herds of Pernambuco and that these isolates have the a great capacity for biofilm formation. It is necessary to sensitize the professionals involved in the milk production chain of Brazil regarding the importance of the adequate use of antimicrobials for the treatment and control of mastitis, since studies in the country indicate the dissemination of resistant bacterial strains.
\end{abstract}

Keywords: bacterial resistance, biofilm, bovine mastitis, Staphylococcus spp. 


\section{INTRODUCTION}

Bovine mastitis is an inflammation that results in a complex interaction among the host, environment and infectious agents [27]. Despite several studies on the diagnosis and control, the disease remains a serious problem for dairy farmers [8,30,53]. Among the agents that cause this disease, Staphylococcus spp. are prominent because of their resistance or capacity to become resistant to many antibiotics $[12,17]$.

The dissemination of bacterial strains that are resistant to beta-lactam antibiotics has been frequently reported, and the $m e c A$ and blaZ genes are considered to be primarily responsible for the resistance mechanisms of this species. The former gene encodes a modified penicillin-binding protein (PBP) that has a low affinity for penicillin-like antibiotics [1]. The blaZ gene is responsible for the expression of beta-lactamase or penicillinases, enzymes that use the beta-lactam ring as a substrate [29].

Biofilm formation is one of the main causes of persistent or chronic bacterial infections [13]. The coexpression of the icaA and icaD genes is fundamental for the complete synthesis of biofilms $[3,39,52]$. The bap gene encodes a protein that promotes primary fixation to surfaces and intercellular adhesion [15].

Studies aimed at characterizing mastitiscausing bacteria are required for reducing the costs associated with the use of inadequate drugs as well as for avoiding the spread of drug-resistant strains. Therefore, this study aimed to phenotypically and genotypically characterize isolates of Staphylococcus spp. obtained from cows with bovine mastitis from the state of Pernambuco, Brazil, and to determine the resistance profiles of these isolates.

\section{MATERIALS AND METHODS}

\section{Isolates and bacterial identification}

In total, 100 isolates of Staphylococcus spp. from the milk samples from cows with clinical or subclinical mastitis were collected from 17 herds (coded from $\mathrm{A}$ to $\mathrm{Q}$ ) in 11 municipalities of the microregion of Garanhuns, in the state of Pernambuco, Brazil. The herds studied represented extensive, semi-intensive or intensive systems, including animals of different breeds, ages and lactation stages. Most of the herds produced more than $500 \mathrm{~L}$ of milk per day, which was collected manually in corrals with no veterinary assistance.
The bacterial agents were identified using morphological characteristics (coloration, size, presence or absence of colony hemolysis), staining (Gram staining) and biochemistry: catalase, Voges Proskauer (VP), coagulase, mannitol fermentation and aerobic fermentation of mannitol and glucose anaerobically. Staphylococcus spp. were classified based on the demonstration of coagulase production [45] and the presence of the nuc gene [23]. The presence of the nuc gene led to classification as $S$. aureus.

\section{Phenotypic test of sensitivity to antimicrobials}

The drug sensitivities of the microorganisms were determined using a modified version of the KirbyBauer disc diffusion method. The isolates were seeded in Mueller-Hinton ${ }^{1}$ broth and incubated at $37^{\circ} \mathrm{C}$ until turbidity was attained according to the McFarland scale (0.5). They were then seeded using swabs in Petri dishes containing Mueller-Hinton agar $^{2}$ as the culture medium. Discs ${ }^{3}$ were impregnated with antimicrobial drugs, including ampicillin $(10 \mu \mathrm{g})$, doxycycline $(30 \mu \mathrm{g})$, erythromycin $(15 \mu \mathrm{g})$, gentamicin $(10 \mu \mathrm{g})$, rifampicin $(30 \mu \mathrm{g})$, cephalothin $(30 \mu \mathrm{g})$, amoxicillin $(10 \mu \mathrm{g})$, nalidixic acid $(30 \mu \mathrm{g})$ and oxacillin (1 $\mu \mathrm{g})$. The dishes were incubated in an incubator for $24 \mathrm{~h}$ at $37^{\circ} \mathrm{C}$. The halo areas were then assessed to determine the sensitivity profiles of the isolates [10].

\section{Phenotypic characterization of biofilm formation}

To assess biofilm formation, phenotypic characterizations of the isolates were carried out using the gentian violet test for adherence to microplates. The isolated colonies were inoculated in $3 \mathrm{~mL}$ of tryptone soya broth with glucose $(0.25 \%)^{2}$ and incubated at $37^{\circ} \mathrm{C}$ for $24 \mathrm{~h}$. Subsequently, $200 \mu \mathrm{L}$ of each mixture was inoculated in micro-dilution plates and again incubated at $37^{\circ} \mathrm{C}$ for $24 \mathrm{~h}$. Next, the samples were washed three times with $200 \mu \mathrm{L}$ distilled water and dried at room temperature. The dishes were stained with $100 \mu \mathrm{L}$ crystal violet $(0.25 \%)^{4}$ for 2 to $3 \mathrm{~min}$ at room temperature. They were then washed three more times with distilled water. To dissolve the dye, $200 \mu \mathrm{L}$ alcohol-acetone was used (80:20, v/v). The optical density (OD) was determined by an ELISA microplate reader ${ }^{5}$ using a $620 \mathrm{~nm}$ filter. All of the samples and the positive and negative controls were analyzed in triplicate. The Staphylococcus aureus ATCC25923 strain was used as the positive control because it was able to produce biofilm. A strain of Staphylococcus epidermidis that did not produce biofilm was used as the negative control. From the arithmetic 
mean of the OD of the isolates calculated from triplicate measurements, it was possible to obtain the OD produced by each isolate (ODi). Based on the mean OD of the negative control (ODc), the microorganisms were classified as follows: non-biofilm former $(\mathrm{ODi} \leq \mathrm{ODc})$ or weak (ODc $<$ ODi $\leq 2 . \mathrm{ODc}$ ), moderate (ODc $<$ ODi $\leq 4$. ODc) or strong (ODi $<4 . \mathrm{ODc}$ ) biofilm former [35].

\section{DNA extraction}

DNA was extracted using an adaptation of the protocols described [6,55]. A fraction of the inoculum was placed in $300 \mu \mathrm{L}$ Tris-EDTA (TE), and the samples were vortexed $^{6}$ for homogenization. Next, $70 \mu \mathrm{L} 10 \%$ SDS was added before further homogenization. Then, $100 \mu \mathrm{L} 5 \mathrm{M} \mathrm{NaCl}_{2}$ and $80 \mu \mathrm{L}$ cetyltrimethylammonium bromide/sodium chloride $(\mathrm{CTAB} / \mathrm{NaCl})$ detergent were added. The samples were incubated at $65^{\circ} \mathrm{C}$ for $20 \mathrm{~min}$. Next, $700 \mu \mathrm{L}$ chloroform/isoamyl alcohol (24:1, v/v) was added and homogenized by inversion. The samples were centrifuged $^{7}$ at $11,750 \mathrm{~g}$ for $5 \mathrm{~min}$. The first phase was transferred to another tube, and $450 \mu \mathrm{L}$ of isopropanol8 was added. The tubes were inverted and left on ice for $20 \mathrm{~min}$. Subsequently, the samples were centrifuged at $11,750 \mathrm{~g}$ for $15 \mathrm{~min}$, the supernatant was discarded, and $500 \mu \mathrm{L} 70 \%$ ethanol ${ }^{8}$ was added. The samples were then centrifuged at $11,750 \mathrm{~g}$ for $10 \mathrm{~min}$, the supernatant was discarded, and the micro-tubes were inverted for drying. The samples were resuspended in $80 \mu \mathrm{L}$ of TE (pH 8.0) and incubated at $65^{\circ} \mathrm{C}$ for $60 \mathrm{~min}$. Finally, the samples were stored at $-20^{\circ} \mathrm{C}$.

\section{Polymerase Chain Reaction (PCR)}

The specific nuc gene was identified for the molecular characterization of the Staphylococcus aureus. The analysis of the genetic potential for resistance to antimicrobials was achieved by the amplification of the mecA and blaZ genes and the assessment of their association with methicillin (oxacillin) and betalactam resistance, respectively. The genetic potential to produce biofilm was assessed by the amplifications of regions of the icaD, icaA and bap genes.

The PCR products were assessed by electrophoresis in an agarose gel (1.5\%), staining with ethidium bromide $\left(1.0 \mathrm{mg} \mathrm{mL}^{-1}\right)$ and visualization under ultraviolet light, followed by documentation using an image capturing system ${ }^{9}$. For the positive controls, a strain of Staphylococcus spp. resistant to methicillin (MRS) and S. aureus ATCC 25923 was used. The primers used are described in Table 1. nuc Gene. The amplification cycles for the analysis of the nuc gene were carried out as described [23] with a number of modifications, including an initial denaturation at $94^{\circ} \mathrm{C}$ for $5 \mathrm{~min}$ followed by 37 cycles at $94^{\circ} \mathrm{C}$ for $1 \mathrm{~min}$, primer hybridization at $55^{\circ} \mathrm{C}$ for $30 \mathrm{~s}$, extension at $72^{\circ} \mathrm{C}$ for $1 \mathrm{~min}$, and a final extension at $72^{\circ} \mathrm{C}$ for $7 \mathrm{~min}$.

$m e c A$ and blaZ Genes. The cycles of amplification of the mecA gene involved an initial denaturation at $94^{\circ} \mathrm{C}$ for $1 \mathrm{~min}$ followed by 15 cycles at $94^{\circ} \mathrm{C}$ for 30 $\mathrm{s}, 68^{\circ} \mathrm{C}$ for $30 \mathrm{~s}$ and $72^{\circ} \mathrm{C}$ for $30 \mathrm{~s}, 20$ additional cycles of $30 \mathrm{~s}$ at $94^{\circ} \mathrm{C}, 30 \mathrm{~s}$ at $60^{\circ} \mathrm{C}$, and $30 \mathrm{~s}$ at $72^{\circ} \mathrm{C}$ and a final extension at $72^{\circ} \mathrm{C}$ for $2 \mathrm{~min}$. The amplification of the blaZ gene consisted of an initial denaturation at $94^{\circ} \mathrm{C}$ for $4 \mathrm{~min}$ followed by 30 cycles at $94^{\circ} \mathrm{C}$ for $1 \mathrm{~min}, 50.5^{\circ} \mathrm{C}$ for $30 \mathrm{~s}$, and $72^{\circ} \mathrm{C}$ for $30 \mathrm{~s}$ and a final extension at $72^{\circ} \mathrm{C}$ for $5 \mathrm{~min}$ [49].

icaD Gene. The amplification of the icaD gene consisted of an initial denaturation at $94^{\circ} \mathrm{C}$ for $2 \mathrm{~min}$ followed by 30 cycles at $92^{\circ} \mathrm{C}$ for $45 \mathrm{~s}, 49.8^{\circ} \mathrm{C}$ for 45 s, and $72^{\circ} \mathrm{C}$ for $1 \mathrm{~min}$ and a final extension at $72^{\circ} \mathrm{C}$ for $7 \mathrm{~min}$ [52].

icaA Gene. The amplification of the icaA gene was performed as described [52] with a number of modifications, including an initial denaturation at $94^{\circ} \mathrm{C}$ for $2 \mathrm{~min}$ followed by 30 cycles at $92^{\circ} \mathrm{C}$ for $45 \mathrm{~s}$, $58.6^{\circ} \mathrm{C}$ for $45 \mathrm{~s}$ and $72^{\circ} \mathrm{C}$ for $1 \mathrm{~min}$ and a final extension at $72^{\circ} \mathrm{C}$ for $7 \mathrm{~min}$.

bap Gene. The amplification of the bap gene was performed as described [15] with a number of modifications, including an initial denaturation at $94^{\circ} \mathrm{C}$ for 2 min followed by 35 cycles at $94^{\circ} \mathrm{C}$ for $45 \mathrm{~s}$, $56.5^{\circ} \mathrm{C}$ for $45 \mathrm{~s}$, and $72^{\circ} \mathrm{C}$ for $50 \mathrm{~s}$ and a final extension at $72^{\circ} \mathrm{C}$ for $5 \mathrm{~min}$.

\section{Statistical analysis}

The kappa coefficient (K) was used to assess the agreement between the presence of the blaZ gene and the presence of beta-lactam resistance, as well as the agreements between microplate adhesion and the presences of the icaA, icaD and bap genes. The conventional interpretation of the $\mathrm{K}$ values was as follows: $0.00-0.20=$ weak agreement; $0.21-0.40=$ regular agreement; $0.41-0.60=$ moderate agreement; $0.61-0.80=$ good agreement; and $0.81-1.00=$ very good agreement. Negative values were interpreted as 0.00 [26]. Bioestat version 5.010 was used for the calculations. 
E.C. Lúcio, G.V. Gouveia, M.M. Costa, et al. 2020. Phenotypic and Genotypic Characteristics and Resistance Profile of

Table 1. Primers used to amplify the genes.

\begin{tabular}{|c|c|c|c|c|}
\hline Gene & Primer & Sequence $\left(5^{\prime}-3^{\prime}\right)$ & Fragment amplified & Reference \\
\hline \multirow{2}{*}{ пис } & пис $F$ & GCGATTGATGGTGATACGGTT & $279 \mathrm{bp}^{\mathrm{a}}$ & [23] \\
\hline & пис $R$ & AGCCAAGCCTTGACGAACTAAAGC & & \\
\hline \multirow{2}{*}{ mecA } & SA - 1 & AAAATCGATGGTAAAGGTTGGC & 214 bp & [37] \\
\hline & SA - 2 & AGTTCTGCAGTACCGGATTTGC & & \\
\hline \multirow{2}{*}{ blaZ } & blaZ F & AAGAGATTTGCCTATGCTTC & $517 \mathrm{bp}$ & [49] \\
\hline & blaZ $R$ & GCTTGACCACTTTTATCAGC & & \\
\hline \multirow{2}{*}{ Ica $\mathrm{D}$} & $i c a D F$ & AAGCCCAGACAGAGGCAATATCCA & $381 \mathrm{bp}$ & {$[52]$} \\
\hline & $I c a D R$ & AGTACAAACAAACTCATCCATCCGA & & \\
\hline \multirow{2}{*}{ IcaA } & $i c a A F$ & CCTAACTAACGAAAGGTAG & $1315 \mathrm{bp}$ & [52] \\
\hline & IcaA $R$ & AAGATATAGCGATAAGTGC & & \\
\hline \multirow{2}{*}{ bap } & bap $F$ & AAGCCCAGACAGAGGCAATATCCA & 971 bp & {$[15]$} \\
\hline & bap $R$ & AGTACAAACAAACTCATCCATCCGA & & \\
\hline
\end{tabular}

abase pairs.

\section{RESULTS}

Ninety-three out of 100 isolates $(93 \%)$ were characterized as Staphylococcus aureus by the presence of the nuc gene. Among the 7 that were not classified as $S$. aureus, $4(57.1 \%)$ were coagulase negative, and $3(42.9 \%)$ were coagulase positive. Of the samples evaluated, only $1(1 \%)$ was associated with clinical mastitis, which the etiological agent involved being $S$. aureus, the other 99 (99\%) samples were associated with sub-clinical mastitis.

Among the Staphylococcus spp., the lowest percentage of sensitivity to antimicrobials was observed for amoxicillin (28\%), followed by ampicillin (29\%), nalidixic acid $(46 \%)$, cephalothin $(83 \%)$, oxacillin $(83 \%)$, rifampicin (84\%) and doxycycline (86\%). All of the isolates were sensitive to erythromycin and gentamicin, and 15 (15\%) exhibited sensitivity to all of the drugs tested. The isolates resistance profile in herds are reported in Table 2.

All of the isolates studied were negative for the mecA gene, whereas the blaZ gene was detected in 36 isolates (36\%). Table 3 displays the blaZ-positive samples in each study herd.

The microplate adherence test showed that $44(44 \%)$ of the Staphylococcus spp. isolates were capable of forming biofilms. Of these, 7 (15.9\%) were strong formers, whereas $16(36.3 \%)$ and 21 $(47.8 \%)$ were moderate and weak formers, respectively. The four coagulase-negative samples were among the 16 with moderate biofilm-formation capacity.

The icaD gene was confirmed in $89(89 \%)$ of the isolates studied and the icaA gene in $61(61 \%)$. Two (50\%) of the CPN that were not classified as S. aureus were confirmed as possessing these two genes. The presence of the bap gene was confirmed in 52 (52\%) of the Staphylococcus spp. samples analyzed, and of them, two were coagulase-negative staphylococci (CNS) (Table 4).

In this study, one CNS sample was positive for the bap gene but negative for ica locus genes, exhibiting moderate biofilm production according to the phenotypic test.

One of the samples did not possess icaA, icaD or bap and exhibited moderate biofilm formation according to the microplate adherence test. Sixteen isolates simultaneously exhibited the 3 genes tested for biofilm production (icaA, icaD and bap) and were negative according to the microplate adherence test.

The 3 CPS samples were negative for all resistance genes and biofilm formation as well as the phenotypic adhesion test microplate.

The results of the analysis of agreement between the presence of the blaZ gene and the presence of antimicrobial resistance, as well as between microplate adherence and the presences of the icaA, icaD and bap genes, are displayed in Table 5. Only weak agreement was observed between the phenotypic and genotypic test results. 
E.C. Lúcio, G.V. Gouveia, M.M. Costa, et al. 2020. Phenotypic and Genotypic Characteristics and Resistance Profile of Staphylococcus spp. from Bovine Mastitis.

Table 2. Resistance profiles of Staphylococcus spp. associated with bovine mastitis in herds from the microregion of Garanhuns, Pernambuco, Brazil.

\begin{tabular}{|c|c|c|c|c|c|c|c|c|c|}
\hline \multirow{2}{*}{ Herd } & \multicolumn{9}{|c|}{ Resistance profile } \\
\hline & $\mathrm{AMO}^{\mathrm{a}}$ & $\mathrm{AMP}^{\mathrm{b}}$ & $\mathrm{NAL}^{\mathrm{c}}$ & $\mathrm{CEP}^{\mathrm{d}}$ & $\mathrm{OXA}^{\mathrm{e}}$ & $\mathrm{RIF}^{\mathrm{f}}$ & $\mathrm{DOX}^{\mathrm{g}}$ & $\mathrm{ERY}^{\mathrm{h}}$ & GEN $^{\mathrm{i}}$ \\
\hline$A(n=24)$ & 21 & 21 & 11 & 12 & 10 & 11 & 2 & 0 & 0 \\
\hline B (n=7) & 7 & 7 & 6 & 2 & 2 & 2 & 1 & 0 & 0 \\
\hline$C(n=8)$ & 4 & 6 & 7 & 1 & 1 & 1 & 1 & 0 & 0 \\
\hline $\mathrm{D}(\mathrm{n}=1)$ & 1 & 0 & 1 & 0 & 0 & 0 & 0 & 0 & 0 \\
\hline $\mathrm{E}(\mathrm{n}=2)$ & 2 & 2 & 2 & 0 & 0 & 0 & 1 & 0 & 0 \\
\hline$F(n=3)$ & 3 & 3 & 3 & 0 & 0 & 0 & 2 & 0 & 0 \\
\hline $\mathrm{G}(\mathrm{n}=1)$ & 1 & 1 & 1 & 0 & 0 & 0 & 1 & 0 & 0 \\
\hline $\mathrm{H}(\mathrm{n}=3)$ & 3 & 3 & 3 & 0 & 0 & 0 & 3 & 0 & 0 \\
\hline $\mathrm{I}(\mathrm{n}=1)$ & 1 & 1 & 1 & 0 & 0 & 0 & 1 & 0 & 0 \\
\hline $\mathrm{J}(\mathrm{n}=2)$ & 2 & 2 & 2 & 0 & 0 & 0 & 0 & 0 & 0 \\
\hline $\mathrm{K}(\mathrm{n}=7)$ & 5 & 4 & 5 & 1 & 2 & 1 & 1 & 0 & 0 \\
\hline $\mathrm{L}(\mathrm{n}=7)$ & 4 & 1 & 3 & 0 & 1 & 0 & 0 & 0 & 0 \\
\hline$M(n=6)$ & 2 & 2 & 2 & 0 & 0 & 0 & 0 & 0 & 0 \\
\hline$N(n=6)$ & 0 & 1 & 2 & 1 & 1 & 1 & 0 & 0 & 0 \\
\hline $\mathrm{O}(\mathrm{n}=19)$ & 13 & 14 & 4 & 0 & 0 & 0 & 1 & 0 & 0 \\
\hline $\mathrm{P}(\mathrm{n}=1)$ & 1 & 1 & 1 & 0 & 0 & 0 & 0 & 0 & 0 \\
\hline $\mathrm{Q}(\mathrm{n}=2)$ & 2 & 2 & 0 & 0 & 0 & 0 & 0 & 0 & 0 \\
\hline Total & 72 & 71 & 54 & 17 & 17 & 16 & 14 & 0 & 0 \\
\hline
\end{tabular}

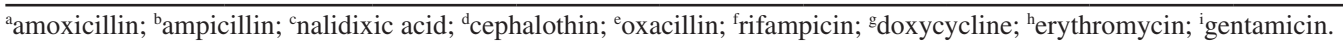

Table 3. The presence of the blaZ gene in isolates of Staphylococcus spp. associated with bovine mastitis in herds from the microregion of Garanhuns, Pernambuco, Brazil.

\begin{tabular}{cc}
\hline Herd & Positive blaZ samples \\
\hline A $(n=24)$ & $8(33.33 \%)$ \\
B $(n=7)$ & $4(57.14 \%)$ \\
C $(n=8)$ & $4(50.00 \%)$ \\
D $(n=1)$ & $1(100 \%)$ \\
E $(n=2)$ & $1(50.00 \%)$ \\
F $(n=3)$ & - \\
G $(n=1)$ & - \\
H $(n=3)$ & - \\
I $(n=1)$ & $1(100 \%)$ \\
J $(n=2)$ & $1(50.00 \%)$ \\
K $(n=7)$ & $4(57.14 \%)$ \\
$L(n=7)$ & $1(14.28 \%)$ \\
M $(n=6)$ & $4(66.66 \%)$ \\
N $(n=6)$ & $2(33.33 \%)$ \\
O $(n=19)$ & $4(21.08 \%)$ \\
P $(n=1)$ & $1(100 \%)$ \\
Q $(n=2)$ & - \\
\hline
\end{tabular}


E.C. Lúcio, G.V. Gouveia, M.M. Costa, et al. 2020. Phenotypic and Genotypic Characteristics and Resistance Profile of

Table 4. The biofilm formation potentials of the samples showing positive results on the phenotypic microplate adherence tests and the presences of the associated genes.

\begin{tabular}{cccc}
\hline Microplate adherence & $i c a \mathrm{D}$ & $i c a \mathrm{~A}$ & bap \\
\hline Strong $(\mathrm{n}=7)$ & $7(100 \%)$ & $6(85.71 \%)$ & $3(42.85 \%)$ \\
Moderate $(\mathrm{n}=12)$ & $12(100 \%)$ & $8(66.66 \%)$ & $8(66.66 \%)$ \\
Weak $(\mathrm{n}=21)$ & $21(100 \%)$ & $16(76.19 \%)$ & $14(66.66 \%)$ \\
Negative $(\mathrm{n}=56)$ & $47(83.92 \%)$ & $30(53.57 \%)$ & $25(44.64 \%)$ \\
\hline
\end{tabular}

Table 5. Agreement between the phenotypic and genotypic tests in relation to the biofilm production capacities and antimicrobial resistance of the isolates.

\begin{tabular}{ccccc}
\hline \multirow{2}{*}{ Phenotypic test } & \multicolumn{3}{c}{ Genotypic test } \\
\cline { 2 - 5 } & icaD & icaA & bap & blaZ \\
\hline $\begin{array}{c}\text { Microplate adherence } \\
\text { Beta-lactam resistance }\end{array}$ & 0.40 & 0.16 & 0.16 & 0.08 \\
\hline
\end{tabular}

\section{DISCUSSION}

With respect to antimicrobial sensitivity, previous study demonstrated a sensitivity of $100 \%$ for gentamicin among staphylococci isolated from bovine mastitis cases from the same region as that of the present study [40]. However, it was also reported $42 \%$ sensitivity to gentamicin among the CPS and associated this finding with the intense use of the drug in the areas studied [17].

In the present study, antimicrobial resistance to three to five drugs was recorded for 45 (45\%) Staphylococcus spp., obtaining similar results to another study, with a $48.6 \%$ strength for bacteria analyzed [38]. However, were also analyzed isolates of Staphylococcus spp. from herds in the state Pernambuco, Brazil, and it was found that $65.6 \%$ were resistant to three or more drugs [24]. In another region of the country had been identified resistance to more than one class of antimicrobials at approximately half of the Staplylococcus spp. studied [46]. The indiscriminate use of drugs to treat mastitis is a common practice in the study area, which may have contributed to the high proportion of herds $(88.23 \%$; $15 / 17)$ with multi-resistant isolates, constituting a selection factor for the dissemination of resistant bacteria among herds.

All of the isolates studied were negative for the mecA gene, including those that exhibited phenotypic resistance according to the tests conducted. It was also found a lack of mecA in 250 samples of Staphylococcus spp. from herds in Rio de Janeiro, stating that there is a need for further studies to investigate the processes of regulation and gene transcription, as well as the product of expression, the PBP2a protein [34]. However, in another study in Rio de Janeiro, the mecA gene was found in cows milk samples in $21(70 \%)$ isolates [43]. Already in the Federal District (Brasília) evaluated 60 samples of Staphylococcus spp. in clinical cases and sub-clinical cases of bovine and bubaline mastitis and found the $m e c A$ gene in one $(3.30 \%)$ of the bubaline samples and three $(10 \%)$ of the bovine samples [21].

The absence of the mecA gene in the present study may be associated with the development of resistant bacteria through another mechanism, such as the overproduction of beta-lactamases [19]. It was suggested that the resistance of $S$. aureus to methicillin (MRSA) is more common in humans than in domestic animals $[20,28,49]$. However, a number of studies have reported the presence of MRSA and MRS in clinical and sub-clinical cases of bovine mastitis, and the associated strains are generally multi-resistant [25].

The blaZ gene was detected in 36 isolates $(36 \%)$, higher number than previously found by other authors who studied isolates from mastitis [34]. It was emphasized the increasing number of reports of isolation producing bacteria of beta-lactamases in animals, and that bacterial isolates resistant to beta-lactams are increasing on a global scale [29]. It is known that the gene responsible for the expression of beta-lactamases is blaZ. 
In the present study, high resistence values were identified for beta-lactam, even though all of the samples were negative for the mecA gene. This finding corroborates the current notion regarding the participation of other mechanisms of resistance, such as the presence of the homologous gene mecC (previously $m e c A_{\mathrm{LGA} 251}$ ), of other types of PBPs (such as PBP3 and PBP4), or mutations in PBPs [5,7,22,42]. It is generally thought that many factors are associated with resistance to beta-lactams, and more detailed investigations, including the identification of different genetic markers of resistance and the regulation of the expression of the mec system, are required for understanding the real value of the presence of this gene in predicting beta-lactam resistance [18,34]. The high percentage of resistant isolates is disconcerting because it indicates that the currently available antibiotics are inefficient, which would hinder or prevent the treatment of mastitis, resulting in higher expenses and risks for dairy owners [17].

With regard to the capacity to produce biofilm, the results of the present study (microplate adherence tests) demonstrated the potential of the isolates to cause infections that are difficult to treat. It was reported that this phenotypic test is one of the most commonly used methods for quantifying biofilm formation by Staphylococcus spp. and that it can function as an indicator of the pathogenicity of microorganisms [50].

The molecular techniques that are used to identify the ica locus by codifying the synthesis of slime are important tools for the accurate identifications of virulent strains that form biofilms [3]. High frequencies of isolates positive for the icaD gene have previously been reported in studies of $S$. aureus obtained from bovine milk [31,52].

The presence of the bap gene was confirmed in $52(52 \%)$ of the Staphylococcus spp. samples analyzed; of them, two were CNS. This result was far bigger than that found in $350 \mathrm{~S}$. aureus samples from cows with mastitis and reported that only $5 \%$ possess the bap gene in association with the strong biofilm production, as determined by phenotypic testing [14]. The presence of the bap gene has previously been described in $S$. aureus and in several CNS species in association with mastitis, including S. epidermidis, S. chromogenes and S. xylosus [51].

A study conducted in Brazil, with samples of milk from cows and heifers from the state of São Paulo, detected by PCR the icaA and icaD genes in $98 \%$ and $100 \%$ of the isolates of $S$. aureus, respectively [9]. Later, the icaA and icaD genes were identified in all $S$. aureus isolates from 3 regions of the country, and the bap gene in $95.6 \%$ of them [47].

In this study, one CNS sample was positive for the bap gene and negative for the ica locus genes, which exhibited moderate biofilm production according to the phenotypic test.

This result corroborates previous findings where it was reported that Staphylococcus spp. that possess the bap gene are strong producers of biofilm, even though most of them do not contain the ica locus genes [51].

A sample classified as CNS that did not possess the icaA, icaD and bap genes exhibited moderate biofilm formation according to the microplate adherence test. Thus, there may be other untested markers that are also associated with the formation and maintenance of biofilms, how the genes fnbA and $f n b B$, IS257 and the locus agr [4,11,16,32,54]. In addition, 16 isolates simultaneously exhibited the three genes tested for biofilm production (icaA, icaD and bap) and were negative according to the microplate adherence test. This can be explained by the subjectivity of phenotypic data. Indeed, it is known that the production of biofilms by bacteria in vitro can be influenced by growth conditions and different mechanisms of adhesion. Furthermore, bacteria grown in vitro may not face the environmental challenges that stimulate the production of biofilms [41].

The analysis of the agreement between the genotypic and phenotypic tests performed on the Staphylococcus spp. isolates showed that all of the genotypic tests were more sensitive than the phenotypic tests. This result may be explained by the subjectivity of the phenotypic data, the absence of environmental challenges that would induce specific expression patterns $[41,44]$.

The lack of availability of laboratory diagnostic resources to agricultural professionals can lead to increasing bacterial resistance because antimicrobials are often administered unnecessarily [36]. The prophylactic management is the most effective means of preventing mastitis, the formation of biofilms, and, consequently, high levels of resistance in microorganisms. Thus, to facilitate the control of mastitis, further studies should be conducted to determine those agents that form biofilms and their associated adhesive mecha- 
nisms [33]. The resistant bacteria such as methicillinresistant Staphylococcus aureus (MRSA), also reflect a problem for public health, because they can be transmitted to humans by direct contact with infected animals or contaminated food, such as milk $[2,48]$.

In conclusion, our results demonstrate that antimicrobial resistance occurs frequently in Staphylococcus spp. that cause bovine mastitis in herds of Pernambuco and that these isolates have a great capacity for biofilm formation. It is necessary to sensitize the professionals involved in the milk production chain of Brazil regarding the importance of the adequate use of antimicrobials for the treatment and control of mastitis, since studies in the country indicate the dissemination of resistant bacterial strains.
MANUFACTURERS

${ }^{1}$ Kasvi Produtos para Laboratórios. Curitiba, PR, Brazil.

${ }^{2}$ HiMedia Laboratories Pvt. Ltd. Mumbai, Maharashtra, India.

${ }^{3}$ Newprov Produtos para Laboratórios. Pinhais, PR, Brazil.

${ }^{4}$ Proquimios Comércio e Indústria Ltda. Rio de Janeiro, RJ, Brazil.

${ }^{5}$ Asys. Cambridgeshire, Cambridge, England.

${ }^{6}$ Phoenix Inc. Phoenix, AZ, USA.

${ }^{7}$ Labnet International Inc. Edison, NJ, USA.

${ }^{8}$ Fmaia Indústria e Comércio Ltda. Cotia, SP, Brazil.

${ }^{9}$ Loccus Biotecnologia. Cotia, SP, Brazil.

${ }^{10}$ Instituto de Desenvolvimento Sustentável Mamirauá. Maraã, AM, Brazil.

Declaration of interest. The authors report no conflicts of interest. The authors alone are responsible for the content and writing of the paper.

\section{REFERENCES}

1 Aarestrup F.M., Seyfarth A.M., Emborg H.D., Pedersen K., Hendriksen R.S. \& Bager F. 2001. Effect of abolishment of the use of antimicrobial agents for growth promotion on occurrence of antimicrobial resistance in fecal Enterococci from food animals in Denmark. Antimicrobial Agents and Chemotherapy. 45(7): 2054-2059.

2 Alba P., Feltrin F., Cordaro G., Porrero M.C., Kraushaar B., Argudín M.A., Nykäsenoja S., Monaco M., Stegger M., Aarestrup F.M., Butaye P., Franco A. \& Battisti A. 2015. Livestock-associated methicillin resistant and methicillin susceptible Staphylococcus aureus sequence type (CC) 1 in European farmed animals: high genetic relatedness of isolates from Italian cattle herds and humans. PloS ONE. 10(8): 1-10.

3 Arciola C.R., Campoccia D., Gamberini S., Cervellati M., Donati M.E. \& Montanaro L. 2002. Detection of slime production by means of an optimized Congo red agar plate based on a colorimetric scale in Staphylococcus epidermidis clinical isolates genotyped for ica locus. Biomaterials. 23(21): 4233-4239.

4 Arciola C.R., Campoccia D., Speziale P., Montanaro L. \& Costerton J.W. 2012. Biofilm formation in Staphylococcus implant infections. A review of molecular mechanisms and implications for biofilm-resistant materials. Biomaterials. 33(26): 5967-5982.

5 Ariza-Miguel J., Hernández M., Fernández-Natal I. \& Rodríguez-Lázaro D. 2014. Methicillin-resistant Staphylococcus aureus harboring mecC in livestock in Spain. Journal of Clinical Microbiology. 52(11): 4067-4069.

6 Ausubel F.M., Brent R., Kingston R.E., Moore D.D., Seidman J.G., Smith J.A. \& Struhl K. 1989. Current Protocols in Molecular Biology. New York: John Wiley \& Sons, pp.16.1-16.8.

7 Ba X., Harrison E.M., Edwards G.F., Holden M.T., Larsen A.R., Petersen A., Skov R.L., Peacock S.J., Parkhill J., Paterson G.K. \& Holmes M.A. 2013. Novel mutations in penicillin-binding protein genes in clinical Staphylococcus aureus isolates that are methicillin resistant on susceptibility testing, but lack the mec gene. Journal of Antimicrobial Chemotherapy. 69(3): 594-597.

8 Bradley A.J. 2002. Bovine mastitis: an evolving disease. The Veterinary Journal. 164(2): 116-128.

9 Castelani L., Pilon L.E., Martins T., Pozzi C.R. \& Arcaro J.R.P. 2014. Investigation of biofilm production and icaA and icaD genes in Staphylococcus aureus isolated from heifers and cows with mastitis. Animal science journal. 86(3): 340-344.

10 Clinical Laboratory Standards Institute (CLSI). 2006. Methods for dilution antimicrobial susceptibility tests for bacteria that grow aerobically: Approved standard. 7th edn. Wayne, PA. (CLSI; 2006). CLSI Document No.:M7-A7.

11 Coelho S.M.O., Pereira I.A., Soares L.C., Pribul B.R. \& Souza M.M.S. 2011. Short communication: profile of virulence factors of Staphylococcus aureus isolated from subclinical bovine mastitis in the state of Rio de Janeiro, Brazil. Journal of Dairy Science. 94(7): 3305-3310.

12 Coelho S.M.O., Reinoso E., Pereira I.A., Soares L.C., Demo M., Bogni C. \& Souza M. 2009. Virulence factors and antimicrobial resistance of Staphylococcus aureus isolated from bovine mastitis in Rio de Janeiro. Pesquisa Veterinária Brasileira. 29(5): 369-374. 
E.C. Lúcio, G.V. Gouveia, M.M. Costa, et al. 2020. Phenotypic and Genotypic Characteristics and Resistance Profile of

13 Costerton J.W., Stewart P.S. \& Greenberg E.P. 1999. Bacterial Biofilms: A Common Cause of Persistent Infections. Science. 284(5418): 1318-1322.

14 Cucarella C., Solano C., Valle J., Amorena B., Lasa I. \& Penades J.R. 2001. Bap, a Staphylococcus aureus surface protein involved in biofilm formation. Journal of bacteriology. 183(9): 2888-2896.

15 Cucarella C., Tormo M.A., Ubeda C., Trotonda M.P., Monzon M., Peris C., Amorena B., Lasa I. \& Penades J.R. 2004. Role of biofilm-associated protein bap in the pathogenesis of bovine Staphylococcus aureus. Infection and Immunity. 72(4): 2177-2185.

16 Dalton H.M. \& March P.E. 1998. Molecular genetics of bacterial attachment and biofouling. Current Opinion in Biotechnology. 9(3): 252-255.

17 Freitas M.F.L., Pinheiro Júnior J.W., Stamford T.L.M., Rabelo S.D.A., Silva D.D., Silveira Filho V.D., Santos F.G.B., Sena M.J. \& Mota R.A. 2005. Perfil de sensibilidade antimicrobiana in vitro de Staphylococcus coagulase positivos isolados do leite de vacas com mastite no Agreste do estado de Pernambuco. Arquivos do Institutito Biológico. 72(2): 171-177.

18 García-Álvarez L., Holden M.T., Lindsay H., Webb C.R., Brown D.F., Curran M.D., Walpole E., Brooks K., Pickard D.J., Teale C., Parkhill J., Bentley S.D., Edwards G.F., Girvan E.K., Kearns A.M., Pichon B., Hill R.L.R., Larsen A.R., Skov R.L., Peacock S.J., Maskell D.J. \& Holmes M.A. 2011. Meticillin-resistant Staphylococcus aureus with a novel mecA homologue in human and bovine populations in the UK and Denmark: a descriptive study. The Lancet Infectious Diseases. 11(8): 595-603.

19 Geha D.J., Uhl J.R., Gustaferro C.A. \& Persing D.H. 1994. Multiplex PCR for identification of methicillin-resistant staphylococci in the clinical laboratory. Journal of Clinical Microbiology. 32(7): 1768-1772.

20 Guérin Faublée V., Carret G. \& Houffschmitt P. 2003. In vitro activity of 10 antimicrobial agents against bacteria isolated from cows with clinical mastitis. Veterinary Record. 152(15): 466-471.

21 Guimarães G., França C.A. \& Krug F.D.S. 2012. Caracterização fenotípica, produção de biofilme e resistência aos antimicrobianos em isolados de Staphylococcus spp. obtidos de casos de mastite em bovinos e bubalinos. Pesquisa Veterinária Brasileira. 32(12): 1219-1224.

22 Haenni M., Châtre P., Tasse J., Nowak N., Bes M., Madec J.Y. \& Laurent F. 2014. Geographical clustering of mecC-positive Staphylococcus aureus from bovine mastitis in France. Journal of Antimicrobial Chemotherapy. 69(8): 2292-2293.

23 Kateete D.P., Kimani C.N., Katabazi F.A., Okeng A., Okee M.S., Nanteza A., Joloba M.L. \& Najjuca F.C. 2010. Identification of Staphylococcus aureus: DNAse and mannitol salt agar improve the efficiency of the tube coagulase test. Annals of Clinical Microbiology and Antimicrobials. 9(1): 23.

24 Krewer C.C., Lacerda I.P.S., Amanso E.S., Cavalcante N.B., Peixoto R.M., Pinheiro Júnior J.W., Costa M.M. \& Mota R.A. 2013. Etiology, antimicrobial susceptibility profile of Staphylococcus spp. and risk factors associated with bovine mastitis in the states of Bahia and Pernambuco. Pesquisa Veterinária Brasileira. 33(5): 601-606.

25 Kumar R., Yadav B.R. \& Singh R.S. 2010. Genetic determinants of antibiotic resistance in Staphylococcus aureus isolates from milk of mastitic crossbred cattle. Current Microbiology. 60(5): 379-386.

26 Landis J.R. \& Koch G.G. 1977. The measurement of observer agreement for categorical data. Biometrics. 33: 159-74.

27 Leblank S.J., Lissemore K.D., Kelton D.F., Duffield T.F. \& Leslie K.E. 2006. Major advances in diseases prevention in dairy cattle. Journal of dairy science. 89(4):1267-1279.

28 Lee J.H. 2006. Occurrence of methicillin-resistant Staphylococcus aureus strains from cattle and chicken, and analyses of their mecA, mecRl and mecI genes. Veterinary Microbiology. 114(1-2): 155-159.

29 Li X.Z., Mehrotra M., Ghimire S. \& Adewoye L. 2007. $\beta$-Lactam resistance and $\beta$-lactamases in bacteria of animal origin. Veterinary Microbiology. 121(3-4): 197-214.

30 Medeiros E.S., França C.A, Krewer C.C., Peixoto R.M., Souza Júnior A.F.S., Cavalcante M.B., Costa M.M. \& Mota R.A. 2011. Antimicrobial resistance of Staphylococcus spp. isolates from cases of mastitis in Buffalo in Brazil. Journal of Veterinary Diagnostic Investigation. 23(4): 793-796.

31 Melchior M.B., Van Osch M.H.J., Graat R.M., Van Duijkeren E., Mevius D.J., Nielen M., Gaastra W. \& FinkGremmels J. 2009. Biofilm formation and genotyping of Staphylococcus aureus bovine mastitis isolates: evidence for lack of penicillin-resistance in Agr-type II strains. Veterinary Microbiology. 137(1-2): 83-89.

32 Melchior M.B., Van Osch M.H.J., Lam T.J.G.M., Vernooij J.C.M., Gaastra W. \& Fink-Gremmels J. 2011. Extended biofilm susceptibility assay for Staphylococcus aureus bovine mastitis isolates: evidence for association between genetic makeup and biofilm susceptibility. Journal of dairy science. 94(12): 5926-5937. 
33 Melo P.D.C., Ferreira L.M., Nader-Filho A., Zafalon L.F. \& Vicente H.I.G. 2012. Phenotypic and molecular analysis of biofilm production by Staphylococcus aureus strains isolated of bovine. Bioscience Journal. 28(1): 94-99.

34 Mendonça E.C., Marques V.F., Melo D.A., Alencar T.A., Coelho I.D.S., Coelho S.M. \& Souza M. 2012. Caracterização fenogenotípica da resistência antimicrobiana em Staphylococcus spp. isolados de mastite bovina. Pesquisa Veterinária Brasileira. 32(9): 859-864.

35 Merino N., Toledo-Arana A., Vergara-Irigaray M., Valle J., Solano C., Calvo E., Lopez J.A., Foster T.J., Penades J.R. \& Lasa I. 2009. Protein A-mediated multicellular behavior in Staphylococcus aureus. Journal of Bacteriology. 191(3): 832-843.

36 Mota R.A., Silva K.P.C., Freitas M.F.L., Porto W.J.N. \& Silva L.B.G. 2005. Utilização indiscriminada de antimicrobianos e sua contribuição a multirresistência bacteriana. Brazilian Journal of Veterinary Research and Animal Science. 42(6): 465-470.

37 Murakami K., Minamide W., Wada K., Nakamura E., Teraoka H. \& Watanabe S. 1991. Identification of methicillinresistant strains of staphylococci by polymerase chain reaction. Journal of Clinical Microbiology. 29(10): 2240-2244.

38 Nader Filho A., Ferreira L.M., Amaral L.A., Rossi Junior O.D. \& Oliveira R.P. 2007. Sensibilidade antimicrobiana dos Staphylococcus aureus isolados no leite de vacas com mastite. Arquivos do Instituto Biológico. 74(1): 1-4.

39 O'gara J.P. 2007. Ica and beyond: biofilm mechanisms and regulation in Staphylococcus epidermidis and Staphylococcus aureus. FEMS Microbiology Letters. 270(2): 179-188.

40 Oliveira A.A.F., Mota R.A., Souza M.I. \& Sá M.E.P. 2002. Perfil de Sensibilidade Antimicrobiana in vitro frente a amostras de Staphylococcus spp. isoladas de mastite subclínica bovina, no Agreste meridional de Pernambuco. Hora Veterinária. 127(22): 8-10.

41 Oliveira M., Bexiga R., Nunes S.F., Carneiro C., Cavaco L.M., Bernardo F. \& Vilela C.L. 2006. Biofilm-forming ability profiling of Staphylococcus aureus and Staphylococcus epidermidis mastitis isolates. Veterinary Microbiology. 118(1-2): 133-140.

42 Paterson G.K., Morgan F.J.E., Harrison E.M., Peacock S.J., Parkhill J., Zadoks R.N. \& Holmes M.A. 2014. Prevalence and properties of mecC methicillin-resistant Staphylococcus aureus (MRSA) in bovine bulk tank milk in Great Britain. Journal of Antimicrobial Chemotherapy. 69(3): 598-602.

43 Pribul B.R., Pereira I.A., Soares L.C., Coelho S.M.O., Barberis I.L., Pascual L. \& Souza M.M.S. 2011. Resistência bacteriana e ação das bacteriocinas de Lactobacillus spp. em Staphylococcus aureus isolados de mastite bovina. Arquivo Brasileiro de Medicina Veterinária e Zootecnia. 63(3): 744-748.

44 Pu W., Su Y., Li J., Li C., Yang Z., Deng H. \& Ni C. 2014. High incidence of oxacillin-susceptible mecA-positive Staphylococcus aureus (OS-MRSA) associated with bovine mastitis in China. PLoS One. 9(2): 1-9.

45 Quinn P.J., Carter M.E., Markey B. \& Carter G.R. 1994. Clinical Veterinary Microbiology. London: Wolfe, 648p.

46 Rabello R.F., Souza C.R.V.M., Duarte R.S., Lopes R.M.M., Teixeira L.M. \& Castro A.C.D. 2005. Characterization of Staphylococcus aureus isolates recovered from bovine mastitis in Rio de Janeiro, Brazil. Journal of Dairy Science. 88(9): 3211-3219.

47 Salimena A.P., Lange C.C., Camussone C., Signorini M., Calvinho L.F., Brito M.A., Borges C.A.V., Guimarães A.S., Ribeiro J.B., Mendonça L.C. \& Piccoli R.H. 2016. Genotypic and phenotypic detection of capsular polysaccharide and biofilm formation in Staphylococcus aureus isolated from bovine milk collected from Brazilian dairy farms. Veterinary research communications. 40(3-4): 97-106.

48 Santiago-Neto W., Machado G., Paim D.S., Campos T., Brito M.A., Cardoso M.R. \& Corbellini L.G. 2014. Age related to the presence of antimicrobial resistant bacteria in twenty one dairy herds in Rio Grande do Sul, Brazil. Pesquisa Veterinária Brasileira. 34(7): 613-620.

49 Sawant A.A., Gillespie S.P. \& Oliver S.P. 2009. Antimicrobial susceptibility of coagulase-negative Staphylococcus species isolated from bovine milk. Veterinary Microbiology. 134(1-2): 73-81.

50 Stepanovic S., Vukovic D., Dakic I., Savic B. \& Vlahovic M.S. 2000. A modified microtiter-plate test for quantification of Staphylococcus biofilm formation. Journal of Microbiological Methods. 40(2): 175-179.

51 Tormo M.A., Knecht E., Gotz F., Lasa I. \& Penades J.R. 2005. Bap-dependent biofilm formation by pathogenic species of Staphylococcus: evidence of horizontal gene transfer? Microbiology. 151(7): 2465-2475.

52 Vasudevan P., Nair M.K., Annamalai T. \& Venkitanarayanan K.S. 2003. Phenotypic and genotypic characterization of bovine mastitis isolates of Staphylococcus aureus for biofilm formation. Veterinary Microbiology. 92(1-2): 179-185. 
E.C. Lúcio, G.V. Gouveia, M.M. Costa, et al. 2020. Phenotypic and Genotypic Characteristics and Resistance Profile of Staphylococcus spp. from Bovine Mastitis. Acta Scientiae Veterinariae. 48: 1759.

53 Vintov J., Aarestrup F.M., Zinn C.E. \& Olsen J.E. 2003. Association between phage types and antimicrobial resistance among bovine Staphylococcus aureus from 10 countries. Veterinary microbiology. 95(1-2): 133-147.

54 Vuong C., Saenz H.L., Gotz F. \& Otto M. 2000. Impact of the agr quorum-sensing system on adherence to polystyrene in Staphylococcus aureus. The Journal of infectious diseases. 182(6): 1688-1693.

55 Wade K.A., Pounder J.I., Cloud J.L. \& Woods G.L. 2005. Comparison of six methods of extracting Mycobacterium tuberculosis DNA from processed Sputum for testing by quantitative real-time PCR. Journal of clinical microbiology. 43(5): 2461-2473. 